\title{
Physicochemical Characteristics, Microstructure and Health Promoting Properties of Green Banana Flour
}

\author{
Minenhle Khoza ${ }^{1, *}$, Eugenie Kayitesi ${ }^{2}$ and Bhekisisa C. Dlamini ${ }^{1}$ \\ 1 Department of Biotechnology and Food Technology, Faculty of Science, DFC Campus, University of \\ Johannesburg, Doornfontein, Johannesburg 2028, South Africa; bcdlamini@uj.ac.za \\ 2 Department of Consumer and Food Sciences, University of Pretoria, Pretoria 0028, South Africa; \\ eugenie.kayitesi@up.ac.za \\ * Correspondence: minenhlek@uj.ac.za; Tel.: +27-(0)11-559-6252
}

check for updates

Citation: Khoza, M.; Kayitesi, E.; Dlamini, B.C. Physicochemical Characteristics, Microstructure and Health Promoting Properties of Green Banana Flour. Foods 2021, 10, 2894. https://doi.org/10.3390/ foods10122894

Academic Editor: Antonello Santini

Received: 20 September 2021

Accepted: 15 October 2021

Published: 23 November 2021

Publisher's Note: MDPI stays neutral with regard to jurisdictional claims in published maps and institutional affiliations.

Copyright: (c) 2021 by the authors. Licensee MDPI, Basel, Switzerland. This article is an open access article distributed under the terms and conditions of the Creative Commons Attribution (CC BY) license (https:/ / creativecommons.org/licenses/by/ $4.0 /)$.

\begin{abstract}
This study aimed to investigate the proximate composition, mineral content, functional properties, molecular structure, in vitro starch digestibility, total phenolic content (TPC), total flavonoid content (TFC) and antioxidant activity (DPPH, FRAP) of green banana flour (GBF) cultivars grown in South Africa. With proximate composition, Finger Rose and Pisang Awak had the highest protein $(4.33 \mathrm{~g} / 100 \mathrm{~g})$ and fat $(0.85 \mathrm{~g} / 100 \mathrm{~g})$ content, respectively. The highest ash content ( $3.50 \mathrm{~g} / 100 \mathrm{~g})$ occurred with both Grand Naine and FHIA-01 cultivars. Potassium and copper were the most abundant and least minerals, respectively. Pisang Awak cultivar had the highest water absorption capacity $(67.11 \%)$, while Du Roi had the highest swelling power $(0.83 \mathrm{~g} / \mathrm{g})$ at $90{ }^{\circ} \mathrm{C}$. Scanning electron microscopy (SEM) images revealed that starch granules from all GBF cultivars were irregular in shape and they had dense surfaces with debris. All the GBF cultivars had similar diffraction patterns with prominent peaks from $15^{\circ}-24^{\circ}$ diffraction angles. The resistant starch (RS) and amylose content of the FHIA-01 cultivar indicates that the GBF has the potential to lower risks of type 2 diabetes and obesity. The highest TPC, TFC and antioxidant activity occurred with the Grande Naine cultivar. Based on their functional characteristics, the Grand Naine and FHIA-01 GBF cultivars could potentially be used as raw materials for bakery products as well as for the fortification of snacks.
\end{abstract}

Keywords: green banana flour; functional characteristics; in vitro starch digestibility; antioxidant activity

\section{Introduction}

The diabetes endemic continues to increase associated with obesity, inactive lifestyles and high-energy diets [1]. These diseases are the leading cause of demise and disability worldwide. Globally 366 million people suffer from diabetes. The International Diabetes Federation predicts this number to rise to 552 million by 2030 [2]. The prevalence of diabetes in South Africa has remarkably increased over the past two decades, making South Africa one of the countries with the highest predictable upsurge in diabetes for the next twenty-five years $[3,4]$. Epidemiological studies show that frequent consumption of high glycemic index (GI) food may lead to a high risk of obesity and type II diabetes. As one of the solutions, studies have indicated that obesity and type II diabetes can be prevented by eating low GI foods such as green banana flour (GBF) [5]. Further, studies have revealed that adequate consumption of fruits and vegetables is vital for reducing the burden of heart diseases and diabetes, possibly due to their relatively high dietary fiber, resistant starch, antioxidants and bioactive compounds contained in these foods [1,6,7]. As a result, there has been an intensive development of secondary food products made from fruits and vegetables as sources of dietary fiber and indigestible starches, with more focus on developing new products. The development of such food products allows the consumer to have permanent access to the nutritional benefits of fruit and vegetable products, in spite of their seasonality, and thus healthy food can be made available throughout the year [8]. 
The use of green banana flour is important as an alternative raw material for the processing of healthy functional products. According to Kumar et al. [9], green banana flour has the following composition: $52.7-54.2 \%$ Resistant starch (RS); $1.81 \%$ Total Soluble Solids (TSS), 76.77\% Total Starch and 14-17\% non-starch polysaccharides. Similar to dietary fiber, starch from green banana flour is not digestible in the small intestine; hence, it is fermented in the colon by gut flora [10]. When RS reaches the colon, it is used as a substrate for microbial fermentation, and it may lead to the production of short-chain fatty acids (butyrate, propionate and acetate), carbon dioxide, hydrogen and methane [11]. Each type of short-chain fatty acid has impacts on health. Butyrate is well-known for health enhancement as it plays a vital role in human gut health, including: decreasing inflammation, reducing the risk for colon cancer and enhancing gut barrier functions [12]. The lower digestibility of RS leads to a reduced release of blood glucose. This has been shown to have a reduction in leptin and post-prandial glucose reactions in people after the consumption of food products with a high RS content [13]. Recently, food products with a low glycemic index are highly favored by consumers due to their resistance to glucoamylase and $\alpha$-amylase. Further, their digestion rate in the gut is relatively low due to the presence of resistance starch, thus causing reduced energy intake by gastral cells $[14,15]$. The aim of the study was to investigate the proximate composition, mineral content, functional, molecular, microstructure, TPC, TFC and antioxidant activity of green banana flour cultivars grown in South Africa.

\section{Materials and Methods}

\subsection{Materials}

Flour from five green banana cultivars, namely Grande Naine, Pisang Awak, Finger Rose, FHIA-01 and Du Roi, was kindly provided by the Agricultural Research Counsel (ARC) Tropical and Subtropical Crops, Nelspruit, Mbombela in South African. All reagents were analytical grade, Trolox, Folin-Ciocalteu reagent, gallic acid and quercetin were purchased from Sigma-Aldrich Pty. Ltd. (Johannesburg, South Africa). The resistant starch assay kit and the amylose/amylopectin kit were purchased from Megazyme Ltd. (Johannesburg, South Africa).

\subsection{Preparation of Banana Starch}

A water-alkaline extraction method was used to prepare banana starch, as described by Jiang et al. [16], with a few changes. Briefly, GBF (100 g) was macerated in distilled water (1 L) for $20 \mathrm{~min}$ at a low speed, then sieved through 100-mesh screens. The collected milk was centrifuged at $4000 \times g$ for $10 \mathrm{~min}$ to remove soluble fiber, and then $1 \mathrm{~L} \mathrm{NaOH}$ solution $(0.2 \%, w / v)$ was added to the sediment. The starch sediment was mixed with water and stirred for $5 \mathrm{~min}$ before resting for $2 \mathrm{~h}$. Thereafter, the sediment was again suspended in water and allowed to settle. This was repeated until the wash water reached a neutral $\mathrm{pH}$. The resultant material was then dried at $45^{\circ} \mathrm{C}$ for $24 \mathrm{~h}$. The desiccated starch was pulverized and passed through a $100 \mu \mathrm{m}$ sieve.

\subsection{Proximate Composition of Green Banana Flour}

The moisture content was assayed using a vacuum oven dryer at $60{ }^{\circ} \mathrm{C}$ for $16 \mathrm{~h}$ using 2-3 g of sample, according to Rodriguez-Jimenez et al. [17]. A furnace was used to measure ash content using a method described by [9]. Soxhlet extraction was used for total fat content [14]. For protein content, the Kjeldahl method was followed, as demonstrated by Kumar et al. [9]. The carbohydrate percentage was calculated using the formula below.

$$
\text { Carbohydrate }(\mathrm{g})=100-(\text { protein }(\mathrm{g})+\text { moisture content }(\mathrm{g})+\text { lipid }(\mathrm{g})+\text { ash }(\mathrm{g}))
$$

\subsection{Mineral Composition of Green Banana Flour}

Mineral analysis was conducted following a method by Jakavula et al. [18]. Briefly, the sample was digested using ultra-pure $\mathrm{HNO} 3$ on a microwave-accelerated reaction system 
(CEM, Matthews, NC, USA). This was conducted at high temperature and pressure for the extraction of acid-extractable elements with the sample material. After that, deionized water was added $(50 \mathrm{~mL}$ ), followed by analyses of the sample by ICP-OES (Thermo Scientific, Basingstoke, UK).

\subsection{Characterization of Functional Properties of Green Banana Flour}

\subsubsection{Water Absorption Capacity (WAC)}

The WAC of GBF was determined using the method described by Kumar et al. [9], with some modifications. Precisely, $0.5 \mathrm{~g}$ flour sample was weighed into $50 \mathrm{~mL}$ centrifuge tubes followed by the addition of $5 \mathrm{~mL}$ distilled water. The suspensions were vortexed and rested for $1 \mathrm{~h}$ at room temperature $\left(26 \pm 2{ }^{\circ} \mathrm{C}\right)$. Thereafter, they were centrifuged at $3000 \mathrm{rpm}$ for $30 \mathrm{~min}$ at $25^{\circ} \mathrm{C}$. The WAC was expressed as $\mathrm{mL}$ of water absorbed per gram of flour.

\subsubsection{Water Solubility Index and Swelling Power}

The water solubility index and swelling power were determined following the method detailed by Kumar et al. [9]. Green banana flour $(0.2 \mathrm{~g})$ was mixed with distilled water $(5 \mathrm{~mL})$ for $30 \mathrm{~s}$ using a vortex. After that, the mixture was heated at $50{ }^{\circ} \mathrm{C}, 70{ }^{\circ} \mathrm{C}$ and $90{ }^{\circ} \mathrm{C}$ for $20 \mathrm{~min}$, followed by cooling and centrifugation at $3000 \mathrm{rpm}$ for $10 \mathrm{~min}$. The supernatant was evaporated at $105{ }^{\circ} \mathrm{C}$ for $16 \mathrm{~h}$ in an oven. The solubility index was calculated as the ratio of the mass of dried supernatant to the mass of the flour expressed in percentage (g/100 g DW). After centrifugation, the filtrate was also weighed to obtain the swelling power.

\subsection{Microstructure Analysis of Green Banana Flour}

\subsubsection{Scanning Electron Microscopy (SEM)}

A scanning electron microscope (SEM-EDX) (JEOL, JSM 7500F) was used to study the microstructures of the banana starch granules. The GBF starch samples were placed on aluminum cylinders that had a double-sided tape followed by coating with carbon. The acceleration voltage was $10.00 \mathrm{kV}$, as previously described by Maziya et al. [19]. An electron beam with the resolution set at a particle size of 20-200 $\mu \mathrm{m}$ was used to view the microstructure of the samples.

\subsubsection{X-Ray Diffraction (XRD)}

The XRD analysis of the GBF samples was determined using Philips X'Pert XRD equipment (Malvern PANalytical, Almelo, The Netherlands). The power source was set at $40 \mathrm{kV}$ and $40 \mathrm{~mA}$ power with a scanning interval of $5^{\circ} / \mathrm{min}$. The scanning range was $2 \theta=5^{\circ}$ to $90^{\circ}[19]$.

\subsection{Molecular Structure Analysis of Green Banana Cultivars}

\subsubsection{Fourier Transform Infrared (ATR-FTIR) Spectroscopy}

The ATR-FTIR spectra of GBF samples were measured using a 4000 FTIR spectrophotometer (JASCO, South Africa). The functional groups of the isolated compound were detected by ATR (JASCO, South Africa) with a diamond crystal plate with a scan rate of 16 runs per scan at a resolution of $4 \mathrm{~cm}^{-1}$ in wavenumbers from 500 to $4000 \mathrm{~cm}^{-1}$ [20].

2.7.2. Determination of Rapidly Digestible, Slow Digestible, Resistant, and Total Starch Contents of Green Banana Flour

The determination of rapidly digestible, slow digestible, resistant, and total starch contents of green banana starch was carried out using a Megazyme Resistant Starch Assay Kit (Megazyme Ltd., Johannesburg, SA). Briefly, the method involved incubating the GBF sample $(80 \mathrm{mg})$ in a mixture of enzymes (pancreatic $\alpha$-amylase and amyloglucosidase) in maleate buffer (pH 6.0) (K-RNTDF; AOAC Method 2017.16) [21]. 


\subsubsection{Amylose and Amylopectin}

A commercial amylopectin/amylose kit (Megazyme Ltd., Johannesburg, South Africa) was used to quantify amylose content. The principle of the method involves the separation of amylopectin and amylose. Thereafter, amylopectin is precipitated with concanavalin-A (Con A), followed by centrifugation to eliminate it Jiang et al. [16].

\subsection{Total Phenols, Flavonoids Content and Antioxidant Properties}

\subsubsection{Total Phenolic Content (TPC)}

The TPC was determined using the Folin-Ciocalteu assay method according to the procedure outlined by Blainski et al. [22]. Briefly, one gram of GBF was mixed with a $25 \mathrm{~mL}$ mixture of methanol and water $(v / v, 20: 5$, respectively) followed by incubation at $37^{\circ} \mathrm{C}$ for $4 \mathrm{~h}$ with shaking. The mixture was then centrifuged $(4000 \times g$ for $10 \mathrm{~min})$. Thereafter, the supernatant was mixed with $500 \mu \mathrm{L}$ deionized water in a test tube with $30 \mu \mathrm{L}$ standard/extracts and $50 \mu \mathrm{L}$ Folin-Ciocalteu reagent (Sigma-Aldrich, Johannesburg, South Africa). This was followed by the addition of $245 \mu \mathrm{L}$ deionized water and $200 \mu \mathrm{L}$ of $\mathrm{Na}_{2} \mathrm{CO}_{3}$. The sample mixture was then incubated at $27^{\circ} \mathrm{C}$ for $30 \mathrm{~min}$, and a microplate reader was used to measure the absorbance $(750 \mathrm{~nm})$. Gallic acid was used as standard, and the results were expressed as mg gallic acid equivalent (GAE)/g dry weight using the standard curve $\left(R^{2}=0.9982\right)$.

\subsubsection{Total Flavonoid Content (TFC)}

The TFC was determined following the method described by Jabri-Karoui et al. [23]. Briefly, where Quercetin (Sigma-Aldrich, Johannesburg, South Africa) was used as a standard. An aliquot of $30 \mu \mathrm{L}$ of each extract or standard \{Quercetin (Sigma-Aldrich, Johannesburg, South Africa)\} was mixed with $20 \mu \mathrm{L}$ of $10 \% \mathrm{AlCl}_{3}$ and $20 \mu \mathrm{L}$ of $2.5 \%$ $\mathrm{NaNO}_{3}$. After $5 \mathrm{~min}, 100 \mu \mathrm{L}$ of $\mathrm{NaOH}$ solution was added to the mixture. From the mixture using a micropipette, $200 \mu \mathrm{L}$ was pipetted into a microplate (96 well). A microplate reader was used to measure the absorbance $(450 \mathrm{~nm})$. The TPC was expressed as $\mathrm{mg}$ $\mathrm{QE} / \mathrm{mg}$ dry weight using the standard curve $\left(\mathrm{R}^{2}=0.9991\right)$.

\subsubsection{Antioxidant Activity}

The antioxidant activity of GBF samples was determined through the use of the ferricreducing-ability-plasma (FRAP) with slight adjustment as described by Hofmann et al. [24]. The method involved the use of 2,2-diphenyl-1-picrylhydrazyl radical (DPPH) to assay the scavenging activity [25] of green banana flour. Trolox stock was used as standard, and the absorbance was read at $517 \mathrm{~nm}$. The results were expressed as $\mu \mathrm{M}$ Trolox equivalent per $100 \mathrm{~g}$ of green banana flour (d.w.).

\subsection{Statistical Analysis}

One-way analysis of variance (ANOVA) was performed using the Statistica statistical software (Version 13.0/September 2015) for data analysis. The significant difference between the samples was determined at $95 \%(p \leq 0.05)$. The results were shown as means \pm standard deviation. The contrast of mean values was analyzed by Fisher Least Significant Difference (LSD) tests. All the experiments were performed in triplicates.

\section{Results and Discussion}

\subsection{Proximate Composition of Green Banana Flour}

The proximate composition of green banana flour (GBF) grown in South Africa is shown in Table 1. The GBF cultivars varied significantly in moisture content, with the Grand Naine and Finger Rose cultivars showing the same and highest $(10.50 \mathrm{~g} / 100 \mathrm{~g}$ d.w.) moisture content, while the FHIA-01 cultivar showed the lowest ( $9.40 \mathrm{~g} / 100 \mathrm{~g}$ d.w.) moisture content. The moisture content of GBF cultivars reported in the current study is within the range generally reported in the literature for unripe/green banana flour. Similar 
to the findings of the present study, Kumar et al. [9] recorded 8.59\% moisture content on green Grand Naine banana flour. Utrilla-Coello et al. [26] reported 7.03\% moisture content for unripe Enano cultivar and $8.96 \%$ for unripe Valery banana cultivar. The moisture content of flour products is critical as it can have an influence on both the physical and chemical properties of foods. It can affect the shelf life and stability of foods since high moisture tends to cause changes in chemical, biochemical and textural properties as well as promoting microbial growth [9]. The relatively low moisture content of the GBF of this study suggests that it could be stable and may have an extended shelf life.

Table 1. Proximate analyses of green banana cultivars grown in South Africa.

\begin{tabular}{cccccc}
\hline \multicolumn{5}{c}{ Parameters (g/100 g d.w.) } \\
\hline Samples & Moisture & Ash & Fat & Protein & Carbohydrate \\
\hline Grande Naine & $10.50 \pm 0.71^{\mathrm{b}}$ & $3.50 \pm 0.11^{\mathrm{b}}$ & $0.52 \pm 0.00^{\mathrm{b}}$ & $3.60 \pm 0.69^{\mathrm{a}}$ & $81.88 \pm 1.4^{\mathrm{a}}$ \\
Pisang Awak & $9.50 \pm 0.33^{\mathrm{a}}$ & $2.50 \pm 0.05^{\mathrm{a}}$ & $0.85 \pm 0.02^{\mathrm{e}}$ & $4.12 \pm 0.48^{\mathrm{c}}$ & $83.03 \pm 0.81^{\mathrm{b}}$ \\
Finger Rose & $10.50 \pm 0.84^{\mathrm{b}}$ & $3.43 \pm 0.31^{\mathrm{b}}$ & $0.70 \pm 0.71^{\mathrm{d}}$ & $4.33 \pm 0.30^{\mathrm{d}}$ & $81.04 \pm 0.76^{\mathrm{a}}$ \\
FHIA-01 & $9.40 \pm 1.34^{\mathrm{a}}$ & $3.50 \pm 0.22^{\mathrm{b}}$ & $0.68 \pm 0.61^{\mathrm{c}}$ & $3.63 \pm 0.77^{\mathrm{a}}$ & $84.82 \pm 0.90^{\mathrm{d}}$ \\
Du Roi & $9.50 \pm 0.51^{\mathrm{a}}$ & $2.46 \pm 0.32^{\mathrm{a}}$ & $0.42 \pm 0.51^{\mathrm{a}}$ & $3.81 \pm 0.43^{\mathrm{b}}$ & $83.81 \pm 0.56^{\mathrm{c}}$ \\
\hline
\end{tabular}

Values with different alphabets in a column indicate significant differences $(p<0.05) . \mathrm{g} / 100 \mathrm{~g}$-gram per hundred grams; d.w.—dry weight basis. $(n=3)$.

The abundance of minerals in GBF has made it a valuable fruit. In this study, the total ash content statistically $(p \leq 0.05$ ) varied from $2.46-3.50 \mathrm{~g} / 100 \mathrm{~g}$ d.w., with the Grand Naine cultivar recording the highest ash content. Campuzano et al. [27] reported an ash content of $2.61 \mathrm{~g} / 100 \mathrm{~g}$ d.w. in GBF (Cavendish), and this is within the range of ash content found in the present study. Elsewhere, Kumar et al. [9] reported ash content of 2.06 and 2.50\% for unripe Grand Naine and Nendran flours, respectively, with the former cultivar relatively lower in ash content than that of the current study. The variation in ash content could possibly be an indication of differences in mineral contents of the GBF cultivars, which can be attributed to agricultural practices and climate change [28] Further, the variations could also be linked to the differences in the type of soil under which they were grown. In general, the ash content of food is associated with a high presence of minerals such as calcium, magnesium, potassium and phosphorus [29].

The protein content of the five GBF cultivars significantly differed $(p \leq 0.05)$. High protein content occurred with the Finger Rose cultivar (4.33\%), while the Grand Naine cultivar had the lowest protein content (3.60\%). The Grand Naine protein content in this study was comparable with the protein content (3.53\%) for the Grand Naine cultivar reported by Kumar et al. [9] on GBF from dessert and plantain banana (Musa spp.). In the study reported by Ferreira et al. [30] a protein Ferreira content of $1.94 \%$ was determined for green banana flour. Elsewhere, Ferreira et al. [31] reported similar protein content $(1.89 \%)$ in unpeeled green banana flour. Bi et al. reported a protein content of $2.90 \%$ for Pisang Awak, which is significantly lower than the $4.12 \%$ found in the present study. The observed variation in results could be due to differences in the soil type and the stage of growth of the fruit [32].

The Pisang Awak cultivar had the highest fat content $(0.85 \mathrm{~g} / 100 \mathrm{~g}$ d.w. $)$ with the lowest fat content recorded for the Du Roi cultivar $(0.42 \mathrm{~g} / 100 \mathrm{~g}$ d.w.) (Table 1$)$. The fat content results reported here are within the range $(0.92-0.93 \mathrm{~g} / 100 \mathrm{~g}$ d.w.) reported by Khoozani et al. [29] in green Cavendish flour. According to Ye et al. [33] low-fat content reduces the extent of starch granule swelling. The low-fat content of banana flour creates an environment that is not suitable for oxidation reactions, resulting in extended shelf life. In fact, it reportedly decreases the risk of lipid oxidation which may result in extended shelf life. Variations in the chemical composition of banana cultivars are associated with various factors, such as regional climate, agronomic methods, harvesting conditions, among others [34]. However, the differences that occurred in the current study are attributed to cultivar variation since the cultivars were grown under the same environmental condition. 


\subsection{Mineral Composition of Green Banana Flour}

The mineral profiles of GBF used in this study are shown in Table 2. In general, potassium (K) was the most abundant (290.95-1033.25 mg/100 g) mineral, while copper $(\mathrm{Cu})$ was the least abundant $(0.25-0.50 \mathrm{mg} / 100 \mathrm{~g})$ mineral among the five GBF cultivars. FHIA-01 recorded the highest amount of $\mathrm{K}(1033.25 \mathrm{mg} / 100 \mathrm{~g})$. The results attained from this study confirm that some banana cultivars (FHIA-01, Grande Naine and Finger Rose, respectively) cultivated in Mpumalanga Province, South Africa, appear to be an excellent source of K. The K level in this study was within the range $(9117.32-14,746.73 \mathrm{mg} / \mathrm{kg}$ ) reported by Tasnim et al. [35] in unripe banana flour cultivars attained from domestic and commercial farms in Limpopo, South Africa. With magnesium, FHIA-01 had the highest concentration (118.15 mg/100 g), while the Finger Rose cultivar had the lowest $(82.10 \mathrm{mg} / 100 \mathrm{~g})$. The research has indicated that the risk of diabetes can be reduced by consuming a high-Mg diet, and this has been associated with the role that $\mathrm{Mg}$ plays in glucose metabolism. Phosphorus (P) was within the range of $31.72-99.25 \mathrm{mg} / \mathrm{kg}$ for all GBF cultivars. There were significant differences $(p \leq 0.05)$ between the content of sulfur (S) amongst the five GBF cultivars. With essential minerals, calcium (Ca) was the least abundant mineral with the lowest concentration observed in the Finger Rose $(8.70 \mathrm{mg} / 100 \mathrm{~g})$ cultivar.

Table 2. Essential minerals in green banana flour from different cultivars (mg/100 g dry weight).

\begin{tabular}{cccccc}
\hline Minerals & Grande Naine & FHIA-01 & Finger Rose & Pisang Awak & Du Roi \\
\hline & & \multicolumn{2}{c}{ Essential macro minerals } \\
$\mathrm{Ca}$ & $18.38 \pm 0.23^{\mathrm{c}}$ & $10.50 \pm 0.33^{\mathrm{b}}$ & $8.70 \pm 0.19^{\mathrm{a}}$ & $28.25 \pm 0.34^{\mathrm{e}}$ & $19.68 \pm 0.41^{\mathrm{d}}$ \\
$\mathrm{Mg}$ & $100.10 \pm 0.17^{\mathrm{d}}$ & $118.15 \pm 0.14^{\mathrm{e}}$ & $82.10 \pm 0.15^{\mathrm{c}}$ & $35.85 \pm 0.38^{\mathrm{b}}$ & $32.4 \pm 0.20^{\mathrm{a}}$ \\
$\mathrm{K}$ & $934.7 \pm 0.11^{\mathrm{d}}$ & $1033.25 \pm 0.15^{\mathrm{e}}$ & $878.95 \pm 0.31^{\mathrm{c}}$ & $501.58 \pm 0.22^{\mathrm{b}}$ & $290.95 \pm 0.35^{\mathrm{a}}$ \\
$\mathrm{P}$ & $99.25 \pm 0.40^{\mathrm{e}}$ & $85.43 \pm 0.12^{\mathrm{d}}$ & $72.50 \pm 0.41^{\mathrm{c}}$ & $38.38 \pm 0.21^{\mathrm{b}}$ & $31.72 \pm 0.38^{\mathrm{a}}$ \\
$\mathrm{S}$ & $77.23 \pm 0.11^{\mathrm{d}}$ & $136.61 \pm 0.21^{\mathrm{e}}$ & $66.69 \pm 0.51^{\mathrm{c}}$ & $55.55 \pm 0.21^{\mathrm{a}}$ & $58.35 \pm 0.12^{\mathrm{b}}$ \\
& & Essential trace minerals & & \\
$\mathrm{Zn}$ & $0.93 \pm 0.21^{\mathrm{e}}$ & $0.53 \pm 0.48^{\mathrm{b}}$ & $0.57 \pm 0.30^{\mathrm{c}}$ & $0.28 \pm 0.33^{\mathrm{d}}$ & $0.18 \pm 0.43^{\mathrm{a}}$ \\
$\mathrm{Cu}$ & $0.5 \pm 1.40^{\mathrm{d}}$ & $0.43 \pm 0.31^{\mathrm{c}}$ & $0.33 \pm 0.22^{\mathrm{b}}$ & $0.33 \pm 0.30^{\mathrm{b}}$ & $0.25 \pm 0.26^{\mathrm{a}}$ \\
$\mathrm{Fe}$ & $2.88 \pm 0.21^{\mathrm{e}}$ & $1.50 \pm 0.27^{\mathrm{c}}$ & $1.33 \pm 0.31^{\mathrm{a}}$ & $2.30 \pm 0.44^{\mathrm{d}}$ & $1.48 \pm 0.42^{\mathrm{b}}$ \\
$\mathrm{Mn}$ & $3.20 \pm 0.41^{\mathrm{e}}$ & $1.23 \pm 0.29^{\mathrm{d}}$ & $0.98 \pm 0.25^{\mathrm{c}}$ & $0.60 \pm 0.21^{\mathrm{b}}$ & $0.48 \pm 0.11^{\mathrm{a}}$ \\
\hline
\end{tabular}

Values with different alphabets in a column indicate significant differences $(p<0.05)$. d.w.-dry weight basis $(n=3)$.

As expected, the overall concentration of macro-minerals was higher than that of trace minerals. The Grande Naine cultivar recorded the highest $(2.88 \mathrm{mg} / 100 \mathrm{~g})$ concentration of iron $(\mathrm{Fe})$, while Finger Rose recorded the lowest $(1.50 \mathrm{mg} / 100 \mathrm{~g})$. The concentration of Fe and $\mathrm{Zn}$ reported in the present study was lower than that reported by Ferreira et al. [36] who reported an Fe concentration of between $8.15-33.72 \mathrm{mg} / \mathrm{kg}$ and a $\mathrm{Zn}$ concentration of $3.55-7.78 \mathrm{mg} / \mathrm{kg}$ for commercial as well as uncommercial unripe banana flour. The Fe concentration of GBF cultivars in this study were higher than that reported by Pessoa et al. [37] (22.5-62.8 mg/kg) in GBF cultivars from Brazil. According to Freeland-Graves et al. [38], food such as beans, bovine liver and seafood are known to be good sources of iron; hence, they are termed "iron-rich foods". Interestingly, the concentration of Fe in GBF cultivars investigated here were similar or higher than that of the aforementioned food products. This means the GBF cultivars could potentially be used as a good source of Fe in foods. The copper $(\mathrm{Cu})$ concentration significantly $(p<0.05)$ varied from $0.25-5.0 \mathrm{mg} / 100 \mathrm{~g}$, with the Grande Naine cultivar showing the highest concentration. The concentration of manganese (Mn) ranged from $0.48-3.2 \mathrm{mg} / 100 \mathrm{~g}$, and the highest and lowest concentrations were observed in Grande Naine and Du Rio cultivars, respectively. Interestingly, the mineral composition of the soil has been reported to influence the mineral content of food crops [38]. Further, the $\mathrm{pH}$ as well as the amount of organic matter in the soil may also influence the mineral content. Other studies have reported similar influence with different agricultural practices and climate change [36,39]. 


\subsection{Characterization of Functional Properties Banana Flours}

\subsubsection{Water Absorption Capacity (WAC) of Green Banana Flour Cultivars}

The WAC indicates the volume occupied by starch granules after swelling in excess of water [34]. It is affected by how much native starch granules have disintegrated. In addition, it is influenced by the physical state of starch, dietary fiber and proteins [40]. In this study, the WAC varied with the type of cultivar (Table 3). Pisang Awak had the highest WAC $(67.11 \%)$, while the least WAC $(40.00 \%)$ was observed with the Finger Rose cultivar. Campuzano et al. [27] reported an almost similar WAC range (48.50-70.00\%) to that of the current study in GBF at different stages of ripeness. Pereira et al. [40] reported $80.00 \%$ WAC for green banana flour. The hydrophilic sites in starch chains allow for interaction with water through hydrogen bonding. The high WAC observed with Pisang Awak GBF here suggests that it could be suitable for baking. It must also be noted that WAC influences gelatinization through available water, and thus, a lower WAC is desirable for a thinner consistency [29].

Table 3. The water absorption capacity of green banana flour cultivars.

\begin{tabular}{cc}
\hline Banana Flour Samples & Water Absorption Capacity (\%) \\
\hline FHIA-01 & $58.01 \pm 0.31^{\mathrm{d}}$ \\
Grande Naine & $43.18 \pm 0.10^{\mathrm{b}}$ \\
Pisang Awak & $67.11 \pm 0.00^{\mathrm{e}}$ \\
Finger Rose & $40.00 \pm 0.58^{\mathrm{a}}$ \\
Du Roi & $50.12 \pm 0.69^{\mathrm{c}}$ \\
\hline
\end{tabular}

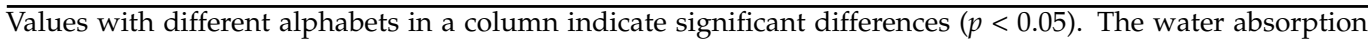
capacity was expressed on a dry weight basis (d.w.). $(n=3)$

\subsubsection{The Water Solubility and Swelling Power of Green Banana Flour Cultivars}

The solubility and swelling power are parameters used to investigate the quality of starch granules. The solubility index is linked to the soluble solid contents in flour, whereas swelling power is a measure of the retention of starch granule integrity when subjected to high cooking temperatures [35,41]. Here, swelling patterns differed amongst the GBF cultivars. The swelling power increased with an increase in temperature with all cultivars (Table 4). Flour from the Du Roi cultivar had the highest swelling power $(0.83 \mathrm{~g} / \mathrm{g})$ at $90^{\circ} \mathrm{C}$, while the FHIA-01 cultivar had the lowest swelling power $(0.52 \mathrm{~g} / \mathrm{g})$ compared to all the other cultivars at the same temperature. The swelling of starch granules follows different stages. First, thermal energy is attained with heating, and this helps to loosen the intra-granular links of starch granules. When the temperature exceeds $70-80{ }^{\circ} \mathrm{C}$, more rapid swelling of starch granules occurs possibly due to intermolecular hydrogen bonds breaking in the amorphous area [42,43]. The current results suggest that swelling of starch granules and high water penetration are attained at high temperatures for the investigated GBF cultivars. The solubility index and swelling power denote the range of interaction within the crystalline (amylose) and amorphous (amylopectin) regions of the starch molecule, along with the degree of branching and the length of branches [29]. Therefore, an increase in solubility index and swelling power cause gelatinization, which is the foundation for making pre-gelatinized starch. According to Khoozani et al. [29] significant differences in swelling may be attributed to low solubility, restricted swelling, the amylose content of flour and slight retrogradation (a reaction that takes place in gelatinized starch, when disaggregated amylopectin and amylose chains reassociate to form more ordered structures). Comparably, low solubility coupled with low swelling power indicates a more well-arranged, denser and strongly bonded granule structure. Another factor that can be attributed to the differences in swelling and solubility indices in the present study could be differences in the starch granule crystallinity. Viscosity patterns, the weak internal organization of starch, can also contribute to variations in solubility and swelling power of flour. The way in which amylose and amylopectin are distributed in the starch granule is thought to be another factor that greatly impacts the solubility index [44]. 
Table 4. The water solubility and swelling index of banana flour (d.w.).

\begin{tabular}{|c|c|c|c|c|c|c|}
\hline \multirow[t]{2}{*}{$\begin{array}{c}\text { Banana Flour } \\
\text { Samples }\end{array}$} & \multicolumn{2}{|c|}{ Solubility (\%) } & \multirow[b]{2}{*}{$90^{\circ} \mathrm{C}$} & \multicolumn{3}{|c|}{ Swelling Power (g/g) } \\
\hline & $50{ }^{\circ} \mathrm{C}$ & $70^{\circ} \mathrm{C}$ & & $50{ }^{\circ} \mathrm{C}$ & $70^{\circ} \mathrm{C}$ & $90^{\circ} \mathrm{C}$ \\
\hline FHIA-01 & $6.49 \pm 0.73^{b}$ & $9.50 \pm 0.71^{d}$ & $15.01 \pm 0.71^{\mathrm{d}}$ & $0.29 \pm 0.71^{\mathrm{a}}$ & $0.42 \pm 0.71^{\mathrm{a}}$ & $0.52 \pm 0.95^{\mathrm{a}}$ \\
\hline Grande Naine & $7.40 \pm 0.00^{c}$ & $9.61 \pm 0.34^{d}$ & $10.21 \pm 0.59^{b}$ & $0.50 \pm 0.19^{d}$ & $0.67 \pm 0.71^{b}$ & $0.75 \pm 0.00^{b}$ \\
\hline Pisang Awak & $6.50 \pm 0.32^{b}$ & $8.47 \pm 0.58^{b}$ & $11.4 \pm 0.58^{c}$ & $0.33 \pm 0.21^{b}$ & $0.38 \pm 0.44^{\mathrm{a}}$ & $0.53 \pm 0.01^{\mathrm{a}}$ \\
\hline Finger Rose & $7.0 \pm 0.08^{c}$ & $9.01 \pm 0.34^{c}$ & $10.21 \pm 0.59^{b}$ & $0.41 \pm 0.79^{c}$ & $0.67 \pm 0.71^{b}$ & $0.79 \pm 0.04^{b}$ \\
\hline Du Roi & $5.50 \pm 0.71^{\mathrm{a}}$ & $7.59 \pm 0.06^{a}$ & $8.03 \pm 0.53^{a}$ & $0.38 \pm 0.24^{\mathrm{c}}$ & $0.63 \pm 0.27^{b}$ & $0.83 \pm 0.54^{c}$ \\
\hline
\end{tabular}

Values with different alphabets in a column indicate significant differences $(p<0.05)$. The results are expressed on a dry weight basis (d.w.). g/g-gram per gram. $(n=3)$.

\subsection{Microstructure Analysis of Green Banana Flour}

\subsubsection{Scanning Electron Microscopy (SEM) of Starch Isolated from Green Banana Flour}

The SEM images of starch isolated from GBF are shown in Figure 1. SEM is used to study the surface morphology, structural integrity, as well as determinations of the size and shape of starch granules. In the present study, SEM revealed that starch granules from GBF were irregular in shape, and they had dense surfaces that had debris. The starch granules diameter ranged from $4.5 \mu \mathrm{m}$ (Finger Rose) to $21.67 \mu \mathrm{m}$ (FHIA-01). According to Reyes-Atrizco et al. [45] banana starch granules can vary from $4-35 \mu \mathrm{m}$ in size, and this is in line with the size of GBF starch granules from this study. Finger Rose and Grand Naine exhibited longer, oval-shaped granules which had fragments on their surfaces. Du Roi granules were intact and elliptical in shape, while Pisang Awak and Finger Rose GBF had smaller and compact granules. The observed variation in GBF starch granules can affect the thermal property and swelling power. In the present study, samples with a bigger granule size had a higher water holding capacity. From the SEM images, it can be observed that the Finger Rose cultivar has the smallest starch granules compared to the other flours. Additionally, FHIA-01, Pisang Awak, Du Roi and Grande Naine had higher water holding capacities compared to Finger Rose, respectively. The SEM images of green banana flour show that there is a correlation between the flour morphology and water holding capacity.
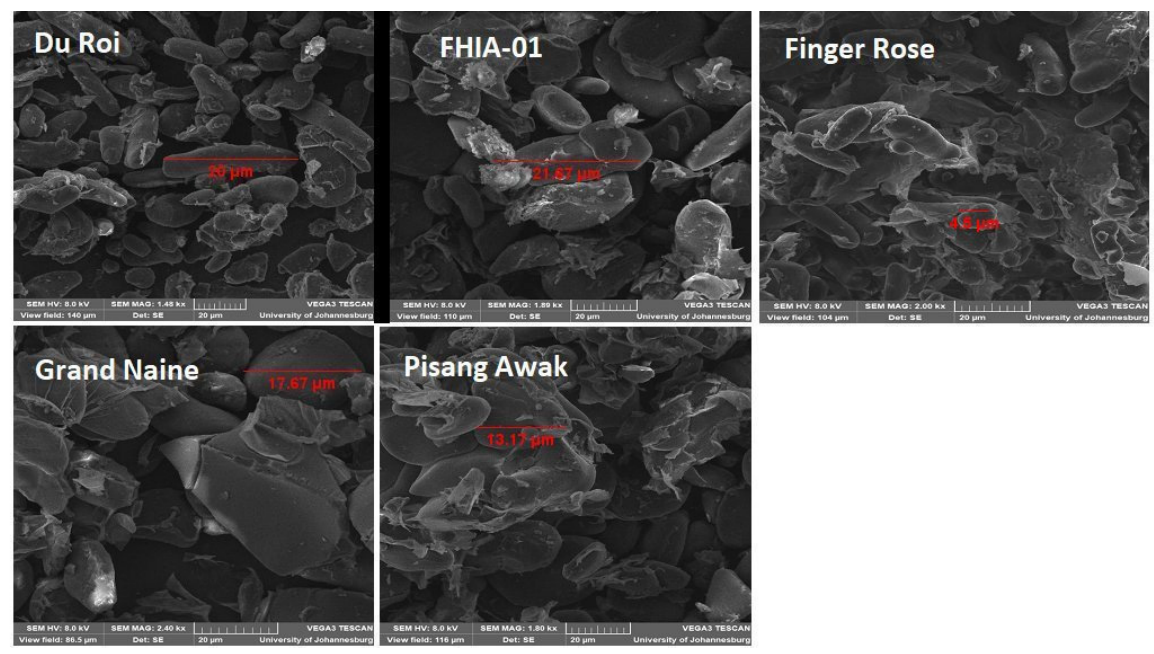

Figure 1. SEM micrographs green banana starch at 2000× Magnifications.

According to Pandey et al. [46] the fragments that can be seen on the surface of the granules are probably amyloplast membranes which enclose starch granules in the banana fruit cell. The findings of the present study are akin to those by Reyes-Atrizco et al. [45] 
who reported that banana flour starch granules appear to be irregularly shaped, elongated and flattened, while the small granules are compact with spheroids and elongated forms.

\subsubsection{X-Ray Diffraction of Green Banana Flour}

There is a semi-crystalline nature of starch particles that can be assessed by XRD. In this study, the crystalline structure of green banana starch granules was analyzed using $X R D$, as shown in Figure 2. All GBF cultivars studied had similar diffraction patterns with prominent peaks at $15.00^{\circ}, 18^{\circ}$ and $24.00^{\circ}$ diffraction angles. The GBF starch granules exhibited XRD patterns with three distinct peaks that were observed as a small peak at $15.00^{\circ}$, strong peak at $18.00^{\circ}$ and a broad peak at $24.00^{\circ}$. Generally, starch granules that originate from different sources appear to have varying crystallization characteristics. The three types of patterns that are displayed by starch are the A pattern (cereal starch), B (tuber, amylo-maize, and retrograded starch) pattern and C pattern (root and seed starches-pea and bean) [46-48]. In line with previous reports, the XRD pattern of green banana starch depicts the B-type crystallinity pattern irrespective of the variety and starch source [48].

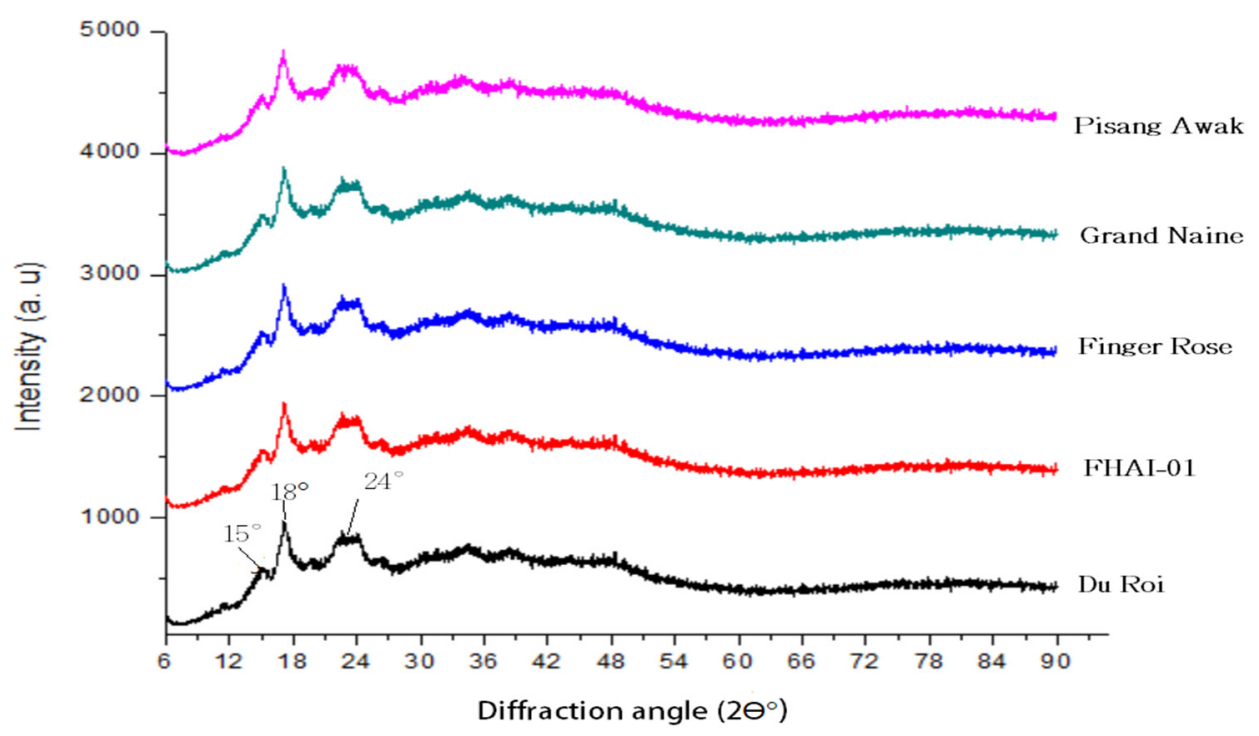

Figure 2. X-ray diffraction patterns of Pisang Awak, Grand Naine, Finger Rose, FHIA-01 and Du Roi.

\subsubsection{Fourier Transform Infrared Spectroscopy (FTIR)}

The FTIR analysis was performed to identify various characteristic functional groups present in the Grande Naine, Finger Rose, Du Roi and Pisang Awak green banana flours as shown in Figure 3. The identification of different functional groups in this study was conducted following the band/group assignments provided in the appendices section. For the Grand Naine, the absorption bands centered around $1643.05 \mathrm{~cm}^{-1}$ and $1002.80 \mathrm{~cm}^{-1}$ show the occurrence of hydroxyl $(-\mathrm{OH})$, amine groups $(-\mathrm{NH})$ and carbonyl group $(=\mathrm{C}=\mathrm{O})$ bonds, respectively [9]. The characteristic absorption bands of Grande Naine were similar to that of previous reports $[9,47,49]$. In general, the absorption bands between $800-1600 \mathrm{~cm}^{-1}$ are defined as the fingerprint region [49] There were characteristic bands of Finger Rose at $1002.80 \mathrm{~cm}^{-1}$, bands between $990 \mathrm{~cm}^{-1}$ and $1160 \mathrm{~cm}^{-1}$, attributed to carbonyl group $(=\mathrm{C}=\mathrm{O})$ bonds stretching. These compounds may contribute to the characteristic flavor and order of the banana flour. For all the analyzed banana flours, bands in similar regions were observed. Similar results have been reported elsewhere in the literature [20]. 


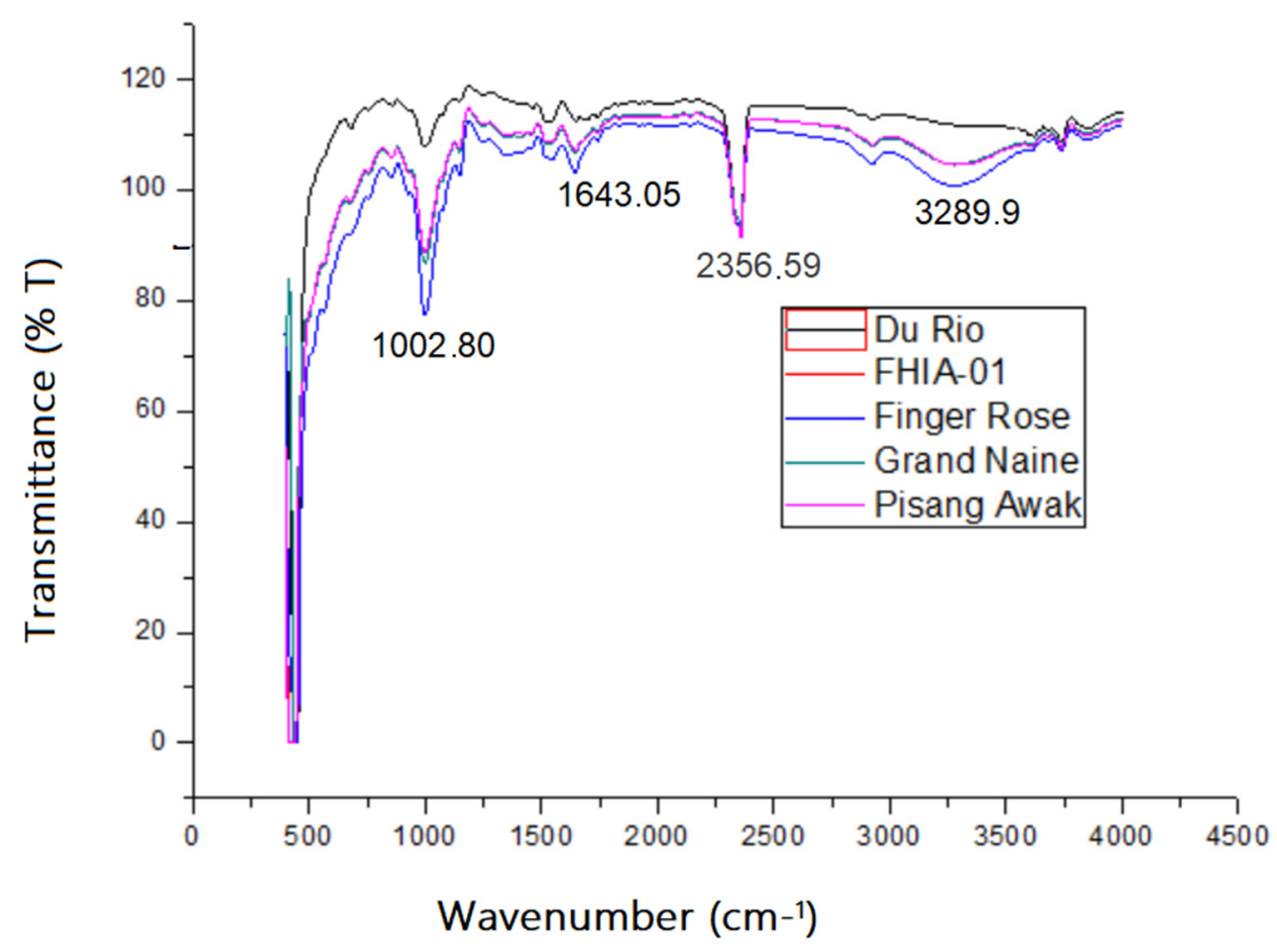

Figure 3. Comparative plots of the FTIR spectra of Du Roi, FHIA-01, Finger Rose, Grand Naine and Pisang Awak.

\subsubsection{In vitro Starch Digestion and Amylose Content of Green Banana Flour}

Since humans generally consume cooked starch more than raw starch, the digestion performance of cooked banana starch is more important to the food industry. The digestibility fractions of green banana starch are indicated in Table 5 . The GBF varied significantly $(p \leq 0.05)$ in their RDS, SDS and RS. Du Roi had the lowest RDS of $4.46 \%$, while Grande Naine $(6.02 \%$ ) had the highest amount of RDS. The SDS ranged from $10.17 \%$ (FHIA-01) to $14.87 \%$ (Finger Rose). FHIA-01 had the highest amount of resistant starch (RS) (86.50\%), while Grande Naine had the lowest amount of RS $(80.38 \%)$. It is widely acknowledged that the GI and RS contents are two significant indicators of starch digestibility $[12,50]$ These findings are an indication that GBF is a source of high RS, which could be linked with a lower GI. This suggests that diets that include GBF can positively influence blood glucose control and can potentially manage diabetes in patients. It is, however, worth noting that the GI of GBF may vary based on protein content, fat content, particle size and maturity and ripeness of the fruit [50]. In a study by Soto-Maldonado et al. [13] on the GI of whole banana and overripe banana pulp, it was observed that extended maturation resulted in an increase in GI, possibly due to a decrease in starch content. In the present study, the RS constituted the highest fraction in the green banana starch. These results are in agreement with the results previously reported for native banana starch $(88.7 \%)$ and native plantain starch ( $85 \%$ ) by Reyes-Atrizco et al. [45]. Recently, the health benefits of RS have been reported to be similar to those of dietary fiber when considering factors such as maintenance of gut homeostasis and promotion of the growth of beneficial gut microflora [50]. Thus, the GBF cultivars in this study may also be used in food applications as pre-biotics. Furthermore, RS is believed to control the amount of glucose released from starchy food, thus lowering the risk of obesity. Since starch is the most available carbohydrate in GBF, it must be noted that carbohydrates in food can influence processing characteristics and the development of designer foods [12]. 
Table 5. Rapidly digestible starch (RDS), slowly digestible starch (SDS), resistant starch (RS) and amylose content green banana flour.

\begin{tabular}{ccccc}
\hline Samples & RDS (\%) & SDS (\%) & RS (\%) & Amylose (\%) \\
\hline Grande Naine & $6.02 \pm 0.11^{\mathrm{c}}$ & $13.30 \pm 0.00^{\mathrm{d}}$ & $80.38 \pm 1.41^{\mathrm{a}}$ & $18.95 \pm 0.98^{\mathrm{b}}$ \\
Pisang Awak & $5.50 \pm 0.05^{\mathrm{b}}$ & $11.73 \pm 0.02^{\mathrm{c}}$ & $84.35 \pm 1.51^{\mathrm{c}}$ & $23.00 \pm 0.91^{\mathrm{d}}$ \\
Finger Rose & $5.43 \pm 0.31^{\mathrm{b}}$ & $14.87 \pm 0.01^{\mathrm{e}}$ & $81.70 \pm 1.21^{\mathrm{b}}$ & $15.55 \pm 0.90^{\mathrm{a}}$ \\
FHIA-01 & $4.50 \pm 0.22^{\mathrm{a}}$ & $10.17 \pm 0.61^{\mathrm{a}}$ & $86.50 \pm 0.21^{\mathrm{e}}$ & $24.82 \pm 0.00^{\mathrm{e}}$ \\
Du Roi & $4.46 \pm 0.82^{\mathrm{a}}$ & $10.42 \pm 0.51^{\mathrm{b}}$ & $85.50 \pm 0.40^{\mathrm{d}}$ & $21.32 \pm 0.16^{\mathrm{c}}$ \\
\hline Values with different alphabets in a column indicate significant differences $(p<0.05) .(n=3)$.
\end{tabular}

There are several properties that are affected by how amylose and amylopectin are arranged in GBF. These include gelatinization, retrogradation as well as digestibility $[25,51]$. Here, a statistically significant $(p<0.05)$ variation in amylose content was observed, with the FHIA-01 cultivar showing the highest amylose content $(24.82 \%)$ and Finger Rose recording the lowest amylose content $(15.55 \%)$. It was also noted that the flours with high amylose content appeared to have high RS content. Thus, we propose that the amylose content could somewhat be positively correlated to the resistant starch. Flour with a higher amylose content is known to have a high solubility index since the amorphous region of starch granules primarily contains high amylose content [52,53]. Previous studies [54-56] suggest that a high amylose content of foods generally tends to give rise to a lower GI. The aforementioned was observed in the present study, as FHIA-01 had the highest amylose content and solubility index in comparison to the other studied GBF.

\subsection{Phenolic Content and Antioxidant Activity of Green Banana Flour}

\subsubsection{Total Phenolic Content and Total Flavonoid Content}

The TPC of GBF cultivars studies here significantly $(p<0.05)$ varied (Table 4$)$. Grand Naine had the highest TPC (524.87 mg GAE/100 g), while Du Roi had the lowest TPC (298.73 mg GAE/100 g). Phenolic compounds are essential secondary metabolites that are relatively high in bananas when compared to other fruits [57] They have been associated with health benefits that include the prevention of several diseases, such as diabetes, obesity and cardiovascular disease. The TPC content of Grand Naine in this study was six times higher than that reported by Anyasi and Mchau [49], possibly because of differences in the stage of ripening, the growth conditions and agricultural practices. Moreover, the extent of maturity has been reported to substantially affect the total phenolic content in green banana flour $[1,24,56]$. Passo et al. [58] reported that over-ripened banana flour had $52 \%$ less phenolic content than GBF, while ripe banana flour had $15-45 \%$ less phenolic content than GBF. Banana flour contains phenolic compounds such as catecholamines, phenolic acids and flavonoids [57,59]. Turola et al. [60] also reported the presence of gallic acid, catechin, epicatechin and myricetin3-O-rhamnosyl-glucoside in ripe and unripe banana flour cultivars. Furthermore, phenolic compounds can be used as food additives in the food industry to prevent lipid oxidation reactions in food formulations. With its high TPC, the Grand Naine cultivar has the potential for being used as a raw material in functional foods. The variation in total phenolic content observed in the present study may be attributed to genetic differences amongst the different banana flours. Bananas contain phenolic compounds such as catecholamines, phenolic acids and flavonoids [49]. The variation in total phenolic content observed in the present results may be attributed to genetic differences amongst different banana flours. Grand Naine recorded higher TFC (407.08 mg QE/100 g) among the flours studied, while Du Roi cultivar had the lowest TFC (287.40 mg QE/100 g). According to Hofmann et al. [24], green banana is abundant in TPC and contains various flavonoids.

\subsubsection{Antioxidant Activity (AOA) of Green Banana Flour}

The antioxidant capacity of GBF is shown in Table 6. Among the cultivars, Grand 
Naine recorded the highest antioxidant activity (437. 22 and $474.23 \mathrm{mg}$ TE/100 g d.w.) by both DPPH and FRAP assays, respectively. The second highest antioxidant activity was recorded with the Finger Rose cultivar and again with both assays. From the results obtained in this study, it is worth noting that cultivars with high TPC showed high antioxidant capacity. Therefore, the finding that Grand Naine was the richest in antioxidant activity was credited to its relative great quantity of phenolic compounds. Previous studies have shown that food with high antioxidants (e.g., carotenoids) can improve immunity in humans. Such a benefit has been linked to the reduction in the occurrence of diseases such as cancer, cardiovascular diseases and diabetes [9]. The health benefits associated with antioxidants are believed to be due to the vital role they play in impeding the initial stages of lipid peroxidation and scavenging singlet oxygen [48]. According to Turola Barbi et al. [61] there is a relationship between DPPH inhibition for plant materials and the TPC and TFC. This was observed through increases in DPPH that occur with an increase in the concentration of phenolic compounds or degree of hydroxylation of the phenolic compounds. Such is consistent with the fact that the antioxidant activity in plants is greatly associated with the phenolic fraction. Although not investigated here, it must be noted that different structures within the same plant contain different concentrations of phenolic compounds $[45,55,62]$. The FRAP assay is commonly used to study the antioxidant capacity of plant materials. In this study, all GBF samples showed a high correlation between the FRAP value and DPPH value. This can be attributed to the fact that both DPPH and FRAP assays generally follow the same mechanism [49]. High correlations between different antioxidant activity methods have also been reported by other researchers [56,57]. The above indicates that banana fruits with high antioxidant capacity could have a high value for their potential health-promoting benefits.

Table 6. Total flavonoid content (TFC), total phenolic content (TPC) of green banana flour.

\begin{tabular}{ccccc}
\hline Samples & $\begin{array}{c}\text { TPC } \\
\text { (mg GAE/100 g } \\
\text { d.w.) }\end{array}$ & $\begin{array}{c}\text { (mg QE/100 g } \\
\text { d.w.) }\end{array}$ & $\begin{array}{c}\text { DPPH } \\
\text { (mg TE/100 g } \\
\text { d.w.) }\end{array}$ & $\begin{array}{c}\text { FRAP } \\
\text { (mg TE/100 g } \\
\text { d.w.) }\end{array}$ \\
\hline FHIA-01 & $307.03 \pm 0.7^{\mathrm{b}}$ & $293.87 \pm 0.91^{\mathrm{b}}$ & $359.11 \pm 0.7^{\mathrm{b}}$ & $411.72 \pm 0.7^{\mathrm{b}}$ \\
Grande Naine & $524.87 \pm 1.6^{\mathrm{d}}$ & $407.08 \pm 1.7^{\mathrm{d}}$ & $437.22 \pm 1.0^{\mathrm{c}}$ & $474.23 \pm 0.2^{\mathrm{c}}$ \\
Pisang Awak & $312.00 \pm 2.1^{\mathrm{b}}$ & $291.80 \pm 0.9^{\mathrm{b}}$ & $363.28 \pm 0.4^{\mathrm{b}}$ & $397.11 \pm 1.1^{\mathrm{b}}$ \\
Finger rose & $321.87 \pm 0.1^{\mathrm{c}}$ & $305.01 \pm 1.0^{\mathrm{c}}$ & $421.00 \pm 0.1^{\mathrm{c}}$ & $448.87 \pm 1.3^{\mathrm{c}}$ \\
Du Roi & $298.73 \pm 1.1^{\mathrm{a}}$ & $287.40 \pm 2.1^{\mathrm{a}}$ & $301.34 \pm 1.1^{\mathrm{a}}$ & $324.27 \pm 0.1^{\mathrm{a}}$ \\
\hline Values with different alphabets in a column indicate significant differences $(p<0.05)$. d.w.-dry weight. $(n=3)$.
\end{tabular}

\section{Conclusions}

The varying functional and physicochemical properties of the GBF cultivars suggest that they can be utilized as raw materials in different food products. The morphological characteristics of the GBF starch and the fact that it appears to be linked to high WAC suggest their possible application in the development of edible films. The GBF were all found to contain relatively high RS, which makes them suitable for the development of low-GI food products. The high TPC, TFC and antioxidant activity in the Grand Naine cultivar suggests its possible use in health-promoting food products. Green banana flour cultivars, such as Pisang Awak, FHIA and Du Roi, indicate that they could be stable when added to food that is processed at a high temperature due to their high amylose content. While, on the other hand, Grand Naine and Finger Rose have low amylose content, which suggests a possible use in food products with low thermal characteristics.

Author Contributions: Conceptualization, M.K., E.K. and B.C.D.; methodology, M.K.; software, M.K.; validation, E.K., B.C.D. and M.K.; formal analysis, M.K.; investigation, M.K.; resources, B.C.D.; data curation, M.K.; writing-original draft preparation, M.K.; writing-review and editing, E.K. and B.C.D.; visualization, E.K.; supervision, B.C.D. and E.K.; project administration, B.C.D.; funding acquisition, E.K. and B.C.D. All authors have read and agreed to the published version of the manuscript. 
Funding: This research was funded by National Research Foundation South Africa (TTK170508230032) and Centre of Excellence-Smart Food Project.

Institutional Review Board Statement: Not applicable.

Informed Consent Statement: Not applicable.

Data Availability Statement: Not applicable.

Acknowledgments: The University of Johannesburg's postgraduate funding supported the research.

Conflicts of Interest: The authors declare no conflict of interest.

\section{References}

1. Rebello, L.P.G.; Ramos, A.M.; Pertuzatti, P.B.; Barcia, M.T.; Castillo-Muñoz, N.; Hermosín-Gutiérrez, I. Flour of banana (Musa AAA) peel as a source of antioxidant phenolic compounds. Food Res. Int. 2014, 55, 397-403. [CrossRef]

2. Wild, S.; Roglic, G.; Green, A.; Sicree, R.; King, H. Global Prevalence of Diabetes: Estimates for the Year 2000 and Projections for 2030. 2004. Available online: http:/ / care.diabetesjournals (accessed on 9 October 2021).

3. Macaulay, S.; Ngobeni, M.; Dunger, D.B.; Norris, S.A. The prevalence of gestational diabetes mellitus amongst black South African women is a public health concern. Diabetes Res. Clin. Pract. 2018, 139, 278-287. [CrossRef]

4. Okaiyeto, K.; Oguntibeju, O.O. Trends in diabetes research outputs in South Africa over 30 years from 2010 to 2019: A biblio-metric analysis. Saudi J. Biol. Sci. 2021, 28, 2914-2924. [CrossRef]

5. Diabetes in South Africa: Assessing the Data with Fear and Trembling. Available online: http:/ /www.statssa.gov.za/publications/ P0302/P03022015.pdf (accessed on 9 October 2021).

6. Ho, L.H.; Abdul Aziz, N.A.; Azahari, B. Physico-chemical characteristics and sensory evaluation of wheat bread partially sub-stituted with banana (Musa acuminata X balbisiana cv. Awak) pseudo-stem flour. Food Chem. 2013, 139, 532-539. [CrossRef] [PubMed]

7. Naknaen, P.; Charoenthaikij, P.; Kerdsup, P. Physicochemical Properties and Nutritional Compositions of Foamed Banana Powders (Pisang Awak, Musa sapientum L.) Dehydrated by Various Drying Methods. Walailak J. Sci. Tech. 2016, 13, 177-191. Available online: http:/ / wjst.wu.ac.th (accessed on 9 October 2021).

8. Martínez, P.; Peña, F.; Bello-Pérez, L.A.; Núñez-Santiago, C.; Yee-Madeira, H.; Velezmoro, C. Physicochemical, functional and morphological characterization of starches isolated from three native potatoes of the Andean region. Food Chem. 2019, 2, 100030. [CrossRef]

9. Kumar, P.S.; Saravanan, A.; Sheeba, N.; Uma, S. Structural, functional characterization and physicochemical properties of green banana flour from dessert and plantain bananas (Musa spp.). LWT 2019, 116, 108524. [CrossRef]

10. Borges, C.V.; Maraschin, M.; Coelho, D.S.; Leonel, M.; Gomez, H.A.G.; Belin, M.A.F.; Diamante, M.S.; Amorim, E.P.; Gianeti, T.; Castro, G.R.; et al. Nutritional value and antioxidant com-pounds during the ripening and after domestic cooking of bananas and plantains. Food Res. Int. 2020, 132, 109061. [CrossRef]

11. Artavia, G.; Cortés-Herrera, C.; Granados-Chinchilla, F. Total and resistant starch from foodstuff for animal and human consumption in Costa Rica. Curr. Res. Food Sci. 2020, 3, 275-283. [CrossRef]

12. Lal, M.K.; Singh, B.; Sharma, S.; Singh, M.P.; Kumar, A. Glycemic index of starchy crops and factors affecting its digestibility: A review. Trends Food Sci. Technol. 2021, 111, 741-755. [CrossRef]

13. Zhang, L.; Xing, R.; Huang, Z.; Zhang, N.; Li, X.; Wang, P. Inhibition of Synovial Macrophage Pyroptosis Alleviates Synovitis and Fibrosis in Knee Osteoarthritis. Mediat. Inflamm. 2019, 2019, 108524. [CrossRef]

14. Kumar, S.R.; Sadiq, M.B.; Anal, A.K. Comparative study of physicochemical and functional properties of pan and microwave cooked underutilized millets (proso and little). LWT 2020, 128, 109465. [CrossRef]

15. Rai, S.K.; Chaturvedi, K.; Yadav, S.K. Evaluation of structural integrity and functionality of commercial pectin based edible films incorporated with corn flour, beetroot, orange peel, muesli and rice flour. Food Hydrocoll. 2019, 91, 127-135.

16. Jiang, H.; Zhang, Y.; Hong, Y.; Bi, Y.; Gu, Z.; Cheng, L.; Li, Z.; Li, C. Digestibility and changes to structural characteristics of green banana starch during invitro digestion. Food Hydrocoll. 2015, 49, 192-199. [CrossRef]

17. Rodriguez-Jimenez, J.R.; Amaya-Guerra, C.A.; Baez-Gonzalez, J.G.; Aguilera-Gonzalez, C.; Urias-Orona, V.; Nino-Medina, G. Physi-cochemical, functional, and nutraceutical properties of eggplant flours obtained by different drying methods. Molecules 2018, 23, 3210. [CrossRef]

18. Jakavula, S.; Biata, N.R.; Dimpe, K.M.; Pakade, V.E.; Nomngongo, P.N. Multi-ion imprinted polymers (MIIPs) for simultaneous ex-traction and preconcentration of $\mathrm{Sb}(\mathrm{III}), \mathrm{Te}(\mathrm{IV}), \mathrm{Pb}(\mathrm{II})$ and $\mathrm{Cd}(\mathrm{II})$ ions from drinking water sources. J. Hazard. Mater. 2021, 416, 126175. Available online: https:/ / linkinghub.elsevier.com/retrieve/pii/S0304389421011390 (accessed on 9 October 2021). [CrossRef] [PubMed]

19. Maziya, K.; Dlamini, B.C.; Malinga, S.P. Hyperbranched polymer nanofibrous membrane grafted with silver nanoparticles for dual antifouling and antibacterial properties against Escherichia coli, Staphylococcus aureus and Pseudomonas aeruginosa. React. Funct. Polym. 2020, 148, 104494. [CrossRef] 
20. Timilsena, Y.P.; Vongsvivut, J.; Tobin, M.J.; Adhikari, R.; Barrow, C.; Adhikari, B. Investigation of oil distribution in spray-dried chia seed oil microcapsules using synchrotron-FTIR microspectroscopy. Food Chem. 2018, 275, 457-466. [CrossRef]

21. Rapid Integrated Total Dietary Fiber Assay Procedure [Internet]. 2020. Available online: www.megazyme.com (accessed on 9 October 2021).

22. Blainski, A.; Lopes, G.C.; De Mello, J.C.P. Application and Analysis of the Folin Ciocalteu Method for the Determination of the Total Phenolic Content from Limonium Brasiliense L. Molecules 2013, 18, 6852-6865. [CrossRef] [PubMed]

23. Jabri-Karoui, I.; Marzouk, B. Bioactive Compounds, Antioxidant Activities and Heat Stability of Corn Oil Enriched with Tunisian Citrus aurantium L. Peel Extract. J. Am. Oil Chem. Soc. 2014, 91, 1367-1375. [CrossRef]

24. Hofmann, T.; Visi-Rajczi, E.; Albert, L. Antioxidant properties assessment of the cones of conifers through the combined evalua-tion of multiple antioxidant assays. Ind. Crop. Prod. 2020, 145, 111935. [CrossRef]

25. Someya, S.; Yoshiki, Y.; Okubo, K. Antioxidant Compounds from Bananas (Musa Cavendish). Available online: www.elsevier. com/locate/foodchem (accessed on 9 October 2021).

26. Utrilla-Coello, R.; Rodríguez-Huezo, M.; Carrillo-Navas, H.; Hernández-Jaimes, C.; Vernon-Carter, E.; Alvarez-Ramirez, J. In vitro digestibility, physicochemical, thermal and rheological properties of banana starches. Carbohydr. Polym. 2014, 101, 154-162. [CrossRef]

27. Campuzano, A.; Rosell, C.M.; Cornejo, F. Physicochemical and nutritional characteristics of banana flour during ripening. Food Chem. 2018, 256, 11-17. [CrossRef] [PubMed]

28. Herrera-Agudelo, M.A.; Miró, M.; Arruda, M.A. In vitro oral bioaccessibility and total content of Cu, Fe, Mn and Zn from transgenic (through cp4 EPSPS gene) and nontransgenic precursor/successor soybean seeds. Food Chem. 2017, 225, 125-131. [CrossRef]

29. Khoozani, A.A.; Kebede, B.; Birch, J.; Bekhit, A.E.-D.A. The Effect of Bread Fortification with Whole Green Banana Flour on Its Physicochemical, Nutritional and In Vitro Digestibility. Foods 2020, 9, 152. [CrossRef]

30. Do Prado Ferreira, M.; Tarley, C.R.T. Bioaccessibility estimation of metallic macro and micronutrients $\mathrm{Ca}, \mathrm{Mg}, \mathrm{Zn}, \mathrm{Fe}, \mathrm{Cu}$ and $\mathrm{Mn}$ in flours of oat and passion fruit peel. LWT 2021, 150, 111880. Available online: https://linkinghub.elsevier.com/retrieve/pii/S0 023643821010331 (accessed on 9 October 2021). [CrossRef]

31. Ferreira, D.C.; Molina, G.; Pelissari, F. Biodegradable trays based on cassava starch blended with agroindustrial residues. Compos. Part B Eng. 2020, 183. [CrossRef]

32. Bezerra, C.V.; Amante, E.R.; de Oliveira, D.C.; Rodrigues, A.M.C.; da Silva, L.H.M. Green banana (Musa cavendishii) flour obtained in spouted bed-Effect of drying on physico-chemical, functional and morphological characteristics of the starch. Ind. Crop. Prod. 2013, 41, 241-249. [CrossRef]

33. Ye, J.; Hu, X.; Luo, S.; McClements, D.J.; Liang, L.; Liu, C. Effect of endogenous proteins and lipids on starch digestibility in rice flour. Food Res. Int. 2018, 106, 404-409. [CrossRef]

34. Amini Khoozani, A.; Birch, J.; Bekhit, A.E.D.A. Production, application and health effects of banana pulp and peel flour in the food industry. J. Food Sci. Technol. 2019, 56, 548-559. [CrossRef] [PubMed]

35. Tasnim, T.; Das, P.C.; Begum, A.A.; Nupur, A.H.; Mazumder, M.d.A.R. Nutritional, textural and sensory quality of plain cake en-riched with rice rinsed water treated banana blossom flour. J. Agric. Food Res. 2020, 2, 100071. [CrossRef]

36. Do Prado Ferreira, M.; Tarley, C.R.T. Assessment of in vitro bioacessibility of macrominerals and trace elements in green banana flour. J. Food Compos. Anal. 2020, 92, 103586. [CrossRef]

37. Brito, A.L.B.; Oliveira, A.F.; Nogueira, A.R.A.; Pessoa, A.G.; Pontes, L.F. Determination of inorganic constituents and physicochemical characterization of functional flour samples. Microchem. J. 2017, 132, 112-118. [CrossRef]

38. Freeland-Graves, J.H.; Sachdev, P.K.; Binderberger, A.Z.; Sosanya, M.E. Global diversity of dietary intakes and standards for zinc, iron, and copper. J. Trace Elem. Med. Biol. 2020, 61, 126515. [CrossRef]

39. Savlak, N.; Türker, B.; Yeşilkanat, N. Effects of particle size distribution on some physical, chemical and functional properties of unripe banana flour. Food Chem. 2016, 213, 180-186. [CrossRef] [PubMed]

40. Pereira, J.; Malairaj, S.; Brohi, S.A.; Boateng, E.F.; Zhang, W. Impact of unripe banana flour on water states, rheological behaviour and structural properties of myofibrillar protein composite gel. LWT 2020, 125, 109276. [CrossRef]

41. Ahmed, J.; Thomas, L.; Khashawi, R. Influence of hot-air drying and freeze-drying on functional, rheological, structural and dielectric properties of green banana flour and dispersions. Food Hydrocoll. 2019, 99, 105331. [CrossRef]

42. Salazar, D.; Arancibia, M.; Lalaleo, D.; Rodríguez-Maecker, R.; López-Caballero, M.E.; Montero, M.P. PHYSICO-CHEMICAL prop-erties and filmogenic aptitude for Edible packaging of Ecuadorian Discard green banana flours (Musa acuminanta AAA). Food Hydrocoll. 2021, 122, 107048. Available online: https://linkinghub.elsevier.com/retrieve/pii/S0268005X21004641 (accessed on 9 October 2021). [CrossRef]

43. Ojha, S.; Bußler, S.; Schlüter, O.K. Food waste valorisation and circular economy concepts in insect production and processing. Waste Manag. 2020, 118, 600-609. [CrossRef] [PubMed]

44. Cui, F.; Zi, H.; Liu, H.; Zhang, S.; Yuan, B. A study of starch-urea-water mixtures with a combination of molecular dynamics sim-ulation and traditional characterization methods. Int. J. Biol. Macromol. 2020, 148, 121-128. [CrossRef]

45. Reyes-Atrizco, J.N.; Agama-Acevedo, E.; Bello-Perez, L.A.; Alvarez-Ramirez, J. Morphological, molecular evolution an in vitro digestibility of filamentous granules of banana starch during fruit development. Int. J. Biol. Macromol. 2019, 132, 119-125. [CrossRef] 
46. Pandey, S.; Kumar, A.; Rao, P.S. Optimization, modeling, and characterization study for the physicochemical properties of raw banana and defatted soy composite extrudates. Food Chem. 2020, 339, 127865. [CrossRef] [PubMed]

47. Rayo, L.M.; e Carvalho, L.C.; Sardá, F.A.; Dacanal, G.; Menezes, E.W.; Tadini, C.C. Production of instant green banana flour (Musa cavendischii, var. Nanicão) by a pulsed-fluidized bed agglomeration. LWT 2015, 63, 461-469. [CrossRef]

48. Mahloko, L.M.; Silungwe, H.; Mashau, M.E.; Kgatla, T.E. Bioactive compounds, antioxidant activity and physical characteristics of wheat-prickly pear and banana biscuits. Heliyon 2019, 5, e02479. [CrossRef]

49. Anyasi, T.; Jideani, A.I.O.; Mchau, G.R. Effect of organic acid pretreatment on some physical, functional and antioxidant properties of flour obtained from three unripe banana cultivars. Food Chem. 2014, 172, 515-522. [CrossRef]

50. Chakravarty, A.; Tandon, M.; Attri, S.; Sharma, D.; Raigond, P.; Goel, G. Structural characteristics and prebiotic activities of re-sistant starch from Solanum tuberosum: Kufri Bahar, a popular Indian tuber variety. LWT 2021, 145, 111445. Available online: https:/ /linkinghub.elsevier.com/retrieve/pii/S0023643821005983 (accessed on 9 October 2021). [CrossRef]

51. Zheng, Y.; Tian, J.; Kong, X.; Yang, W.; Yin, X.; Xu, E.; Chen, S.; Liu, D.; Ye, X. Physicochemical and digestibility characterisation of maize starch-caffeic acid complexes. LWT 2019, 121, 108857. [CrossRef]

52. Lawal, O.S.; Lapasin, R.; Bellich, B.; Olayiwola, T.O.; Cesàro, A.; Yoshimura, M.; Nishinari, K. Rheology and functional properties of starches isolated from five improved rice varieties from West Africa. Food Hydrocoll. 2011, 25, 1785-1792. [CrossRef]

53. Alimi, B.A.; Workneh, T.S. Structural and physicochemical properties of heat moisture treated and citric acid modified acha and iburu starches. Food Hydrocoll. 2018, 81, 449-455. [CrossRef]

54. Navghare, V.V.; Dhawale, S.C. In vitro antioxidant, hypoglycemic and oral glucose tolerance test of banana peels. Alex. J. Med. 2017, 53, 237-243. [CrossRef]

55. Vu, H.T.; Scarlett, C.J.; Vuong, Q.V. Phenolic compounds within banana peel and their potential uses: A review. J. Funct. Foods 2018, 40, 238-248. [CrossRef]

56. Passo Tsamo, C.V.; Herent, M.F.; Tomekpe, K.; Happi Emaga, T.; Quetin-Leclercq, J.; Rogez, H.; Larondelle, Y.; Andre, C. Phenolic profiling in the pulp and peel of nine plantain cultivars (Musa sp.). Food Chem. 2015, 167, 197-204. [CrossRef] [PubMed]

57. Anyasi, T.A.; Jideani, A.I.; Mchau, G.R. Phenolics and essential mineral profile of organic acid pretreated unripe banana flour. Food Res. Int. 2017, 104, 100-109. [CrossRef] [PubMed]

58. Aydogdu, A.; Yildiz, E.; Aydogdu, Y.; Sumnu, G.; Sahin, S.; Ayhan, Z. Enhancing oxidative stability of walnuts by using gallic acid loaded lentil flour based electrospun nanofibers as active packaging material. Food Hydrocoll. 2019, 95, 245-255. [CrossRef]

59. Ayseli, M.T.; Yilmaz, M.T.; Cebi, N.; Sagdic, O.; Ozmen, D.; Capanoglu, E. Physicochemical, rheological, molecular, thermal and sensory evaluation of newly developed complementary infant (6-24 months old) foods prepared with quinoa (Chenopodium quinoa Willd.) flour. Food Chem. 2020, 315, 126208. [CrossRef] [PubMed]

60. Barbi, R.C.T.; Hornung, P.S.; Ávila, S.; Alves, F.E.D.S.B.; Beta, T.; Ribani, R.H. Ripe and unripe inajá (Maximilia maripa) fruit: A new high source of added value bioactive compounds. Food Chem. 2020, 331, 127333. [CrossRef]

61. Naseer, B.; Naik, H.; Hussain, S.Z.; Bhat, T.; Nazir, N. Development of instant phirni mix (a traditional dairy dessert) from high amylose rice, skim milk powder and carboxymethyl cellulose-resistant starch, predicted glycemic index and stability during storage. Food Biosci. 2021, 42, 101213. [CrossRef]

62. Tuaño, A.P.P.; Barcellano, E.C.G.; Rodriguez, M.S. Resistant starch levels and in vitro starch digestibility of selected cooked Philippine brown and milled rices varying in apparent amylose content and glycemic index. Food Chemistry: Molecular Sciences. 2021, 2, 100010. 